\title{
SUSTAINABILITY IN ENGINEERING EDUCATION - DESCRIPTION AND COMPARISON OF TWO UNIVERSITY COURSES
}

\author{
Kattwinkel, Daniela (1); \\ Heide, Ludger (2); \\ Syré, Anne (2); \\ Grahle, Alexander (2); \\ Bender, Beate (1); \\ Göhlich, Dietmar (2) \\ 1: Ruhr-Universität Bochum; \\ 2: Technische Universität Berlin
}

\begin{abstract}
Sustainable products are becoming increasingly important for companies in order to succeed. However, the development of sustainable products poses a complex challenge, because alongside the classical product development requirements, additional social, economic and ecologic requirements arise. Despite the increasing relevance of this topic, sustainability is not yet fully integrated into the product development processes and mindsets within companies. Simultaneously, the integration of sustainability into engineering education is still insufficient and traditional teaching formats seem to be inadequate to teach such complex and multifaceted topics. Within this publication, the development, the contents and the implementation of two different university engineering courses for sustainability and environmentally compatible product development are described and compared. The different approaches to develop and incorporate sustainability into the engineering education and the usage of innovative teaching concepts are demonstrated to encourage and inspire other universities.
\end{abstract}

Keywords: Sustainability, Ecodesign, Design education, Sustainability education, Teaching Concepts

\section{Contact:}

Kattwinkel, Daniela

Ruhr-Universitaet Bochum

Product Development

Germany

kattwinkel@1pe.rub.de

Cite this article: Kattwinkel, D., Heide, L., Syré, A., Grahle, A., Bender, B., Göhlich, D. (2021) 'Sustainability in Engineering Education - Description and Comparison of Two University Courses', in Proceedings of the International Conference on Engineering Design (ICED21), Gothenburg, Sweden, 16-20 August 2021. DOI:10.1017/pds.2021.547 


\section{INTRODUCTION}

Sustainability is an attribute that politics and society are increasingly demanding of technical products and processes (Jensen, 2019). The development of a sustainable product is a complex challenge, which always involves weighing conflicting technological, economic, ecological and social aspects (Birkhofer et al., 2018). Nevertheless, sustainability and related topics such as environmentally compatible product development (Ecodesign) have not been fully adopted by the product development practice in the industry. Developing sustainable products requires a new mindset, new design processes and dealing with long term implications across a broad scope of impact categories, which cannot always be quantified. One part of the journey to achieve these skills is to include sustainable product development in engineering education. Especially such complex and multifaceted subjects call for didactically suitable teaching formats, to achieve a long-lasting learning success.

However, in most engineering courses, traditional teaching formats still dominate, although they are not in accordance with current findings of academic didactics (Preißler et al., 2010). The so called "shift from teaching to learning", that is part of the Bologna Process ${ }^{1}$, implies a change of paradigm away from a teacher and input oriented instruction towards a teaching that focuses on the process of learning and on the output in the form of competences. All different competence definitions that emerged from the discussions relating to the Bologna Process result in the same and critical basic approach: a competence based university education focuses on the active, self-regulated and self-responsible learning of the students (Ouden and Rottlaender, 2017).

In Germany, only a few universities with an engineering focus have taken up sustainability as a teaching subject, so far (Kattwinkel and Bender, 2020). Some of the existing courses such as "Blue Engineering" (Blue Engineering, 2020), which is being taught at seven German universities, focus on creating awareness but lack the practical tools and skills to improve the sustainability of products (Pongratz and Baier, 2015). Other more practical courses focus solely on selective solutions like sustainable energy generation or resource efficient design without enabling a holistic view on sustainability.

For this reason, the following questions will be answered in this paper: Which contents should be addressed in courses that both create awareness of sustainability in engineering and teach approaches and tools in a practical manner? Which innovative teaching methods are suitable to communicate these contents? How can such courses be developed? In this paper, we address these questions using two recently developed courses at two German universities as examples: firstly, the course "Entwicklungsmethoden für nachhaltige Produkte" (Development Methods for Sustainable Products) ${ }^{2}$ at Technische Universität Berlin (TUB) and secondly, the course "Umweltgerechte Produktentwicklung" (Environmentally compatible product development) ${ }^{3}$ at Ruhr-University Bochum (RUB). By means of this direct comparison of two innovative teaching concepts and the development work behind them, we intend to encourage and inspire other universities and departments in the field of engineering education to take up such projects as well. Evidently, education is an effective way to enable a young generation of engineers to recognize sustainability challenges of today's technology and to find solutions to solve them.

\section{THE COURSE “ENTWICKLUNGSMETHODEN FÜR NACHHALTIGE PRODUKTE”}

\subsection{University and Chair}

The course takes place at Technische Universiät Berlin (TU Berlin) (TU Berlin, 2020), where around 33,000 students are enrolled. It is offered by the Department "Methods for Product Development and Mechatronics" (MPM) (MPM Team, 2020). In teaching and research, MPM was mostly concerned with classical mechanical engineering design. In recent years, however, the exploration of new concepts of electromobility became another focus of the department and with that, sustainability issues and life cycle analysis came into scope.

\footnotetext{
${ }^{1}$ The Bologna Process describes the harmonization and updating of the European higher education.

${ }^{2}$ www.mpm.tu-berlin.de/menue/studium_und_lehre/master/entwicklungsmethoden_fuer_nachhaltige_produkte

${ }^{3}$ www.lmk.ruhr-uni-bochum.de/aktuell/akt00139.html.de
} 


\subsection{Development}

The initial motivation for the course results from a perceived lack of an advanced sustainable engineering design course available for engineering students. An analysis of the current courses at TU Berlin shows this deficit in solving technical problems, while explicitly addressing sustainability holistically. On the one hand "Blue Engineering" (Pongratz and Baier, 2015) and other courses established in this area provide engineering students with an introduction, showing the need for a sustainable future and critically reflecting the role of engineering and technology in achieving such a future. However, they tend to focus more on motivating the need for "better engineering" and showing the limits of engineering solutions for social problems rather than presenting specific methods to design products. On the other hand many departments from the area of environmental engineering offer specific courses addressing certain aspects of sustainable design such as the design of wind turbines. However, those courses are not embedding and generalizing sustainability topics into the engineering design process.

As a consequence, a multidisciplinary team of researchers at TU Berlin developed the course "Entwicklungsmethoden für nachhaltige Produkte". Multiple workshops were held, going from abstract goals to specific planning of the lectures. The overall concept is developed by addressing the perceived shortcomings of current engineering teaching and the experience of the instructors.

During the development of the course, special consideration was paid to the atmosphere of the lecture. With the "shift from teaching to learning" and the different perspective on engineering required for sustainable engineering as outlined in the introduction, a different atmosphere to the usual engineering lecture is necessary. We focus on an eye-level approach, teaching the methods not as "settled knowledge" taught by experts but rather as pathways to solutions that will need to be refined and developed further.

\subsection{Learning Outcomes and Assessment}

Based on the outcomes of the workshops, the following three phases of the course were conceived. The first phase is dedicated to the recognition of problems: the students experience how to critically question existing products or processes and learn methods to make the effects on the environment or society measurable. In the second phase, they learn how the sustainability requirements create conflicts with existing requirements. Approaches and the dealing with conflicts are discussed. In the third phase, concrete tools are taught and applied in an exemplary manner, which concretely implements the previously described sustainability requirements in the products. The three phases are accompanied by the ecological, social and economic dimensions of sustainability. This concept is visualized in Figure 1.

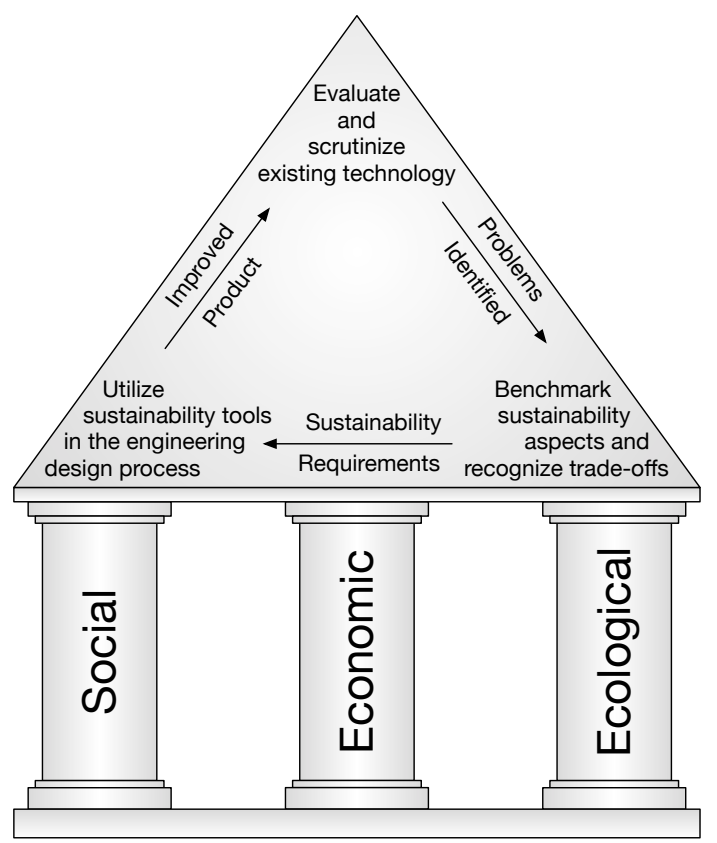

Figure 1. Main phases and core concepts of the course "Entwicklungsmethoden für nachhaltige Produkte". 
The central learning outcomes can be summarized as follows:

After the completion of the course, the students will be able to...

- $\quad . .$. remember and understand the three dimensions of sustainability.

- $\quad .$. analyze and evaluate the sustainability aspects of products - on a qualitative and quantitative scale.

- $\quad . .$. are aware of the possibilities and limits of achieving sustainability through technology.

- ... apply skills in a teamwork based project to create an exemplary product.

The examination concept is developed based on the learning outcomes for the course. The categories knowledge, skill and competency are used as defined by the European Commission for Education (European Commission - Education and Culture, 2008). The key goals of this lecture are conveying skills and competences, with knowledge being required but not a focus of this lecture. Based on this, a three-part examination is created.

- Journal: Students individually write up their experience with each lecture, indicating both what was taught but also what examples they can apply it to and whether they agree with the assumptions of the lecture. The main goal of this examination part is the reflection of the course content itself and the possible change in students' attitudes.

- Project Report: In the project report, the knowledge and skills are to be applied to a given technical product. For each lecture, sub-tasks are created that apply the key goals and methods of the course to a given product - for the first iteration, the product is a smartphone.

- Presentation: Students are to present their report in a group, focusing on a specific part of their solution so that different groups create substantially different presentations.

\subsection{Content}

The course is split into six modules: Technology and values; technology assessment; requirements analysis; energy and material; working environment; and construction methods. The subject area technology and values introduces engineering students to core concepts of the philosophy of technology: Theories on why technology is developed as well as Poser's concept of Technodicee (Poser, 2016), which tries to explain the duality of "perfect" technology being impossible to achieve while "better" technology is essential for humanity's continued survival. Technology assessment deals with products and their effects based on the VDI 3780 standard (Verein Deutscher Ingenieure, 2000), explaining basic concepts of technology assessment and the relationship between technology and society. Small groups of students discuss the topics of moral values in the technical context, physical and societal boundary conditions for technology development, and competing or instrumental relationships between development goals. In the area of requirements analysis, the focus is on turning abstract development goals into measurable and achievable requirements. Existing technology is analyzed and reverse engineered in order to demonstrate the trade-offs made in the real world. Energy and Material first deals with the basics of material flow analysis (Brunner and Rechberger, 2016). Then the methods life cycle assessment (LCA) according to DIN EN ISO 14040 (DIN e. V., 2009), life cycle cost analysis (Dhillon, 2009) and social life cycle assessment (Benoit and Mazijn, 2009) are presented. In the field of the working environment, the working environments of both engineers and producers are covered. In the working environment of the engineers both the social and economic responsibility of the profession and the personal well-being under constantly increasing alienation and high responsibility with little flexibility to make decisions is in the focus (Böhle, 2017). Furthermore, concepts like corporate social responsibility are addressed. Also the working environment of the producers is discussed. Here the focus is on the interaction of design decisions and working conditions. In the area of design methods, the focus is on the sustainable design (Buchert et al., 2014) of products. This area consists of three topics: EcoDesign, Design for Economy and Design for Social Sustainability. Several specific methods are taught in those three areas.

\subsection{Implementation}

Prior to the respective module, the lecturers provide input in form of articles, TED talks, podcasts and videos. The students acquire the theoretical contents with the help of the provided materials in selfstudy. During the course, first, the students discuss and summarize the theoretical content and answer open questions, the lecturers act as moderators and join the discussion or give explanation if needed. Subsequently, interactive elements such as group discussions, class quizzes and exercises are performed 
to practice the application of the taught methods. Due to the COVID-19 Pandemic, the first run of the course is held online, which was originally not intended. Therefore, the theoretical input is presented with the help of a MOODLE-based (Moodle Contributors, 2020) learning platform, the actual course is held using video communication and visual collaboration tools. In the upcoming semesters, the intention is to teach the course in presence as planned. However, the experience gained in digital teaching can be further used, for example, to provide instructional videos for the preparation of the modules.

\section{THE COURSE “UMWELTGERECHTE PRODUKTENTWICKLUNG”}

\subsection{University and Chair}

The Ruhr-University Bochum is one of the largest universities in Germany with over 42,000 enrolled students (Ruhr-Universität Bochum, 2020). The Chair of Product Development (LPE) at the Faculty of Mechanical Engineering educates engineering students in the subjects product development, design, mechatronics and biomechanics. The LPE pursues the goal of training creative "problem solvers", who are able to analyze and abstract complex challenges with conflicting objectives (e.g. cost, time, quality, ecology) and to develop innovative solutions. To further support the education of students beyond the classical engineering topics, the chair has therefore successfully applied for the project "EcoING Entwicklung und Umsetzung einer Ecodesign-Lernfabrik für die universitäre Ingenieurausbildung" (Development and implementation of an Ecodesign Learning Factory for the university engineering education) at the Deutsche Bundesstiftung Umwelt (DBU).

\subsection{Development}

The goal of the project EcoING is the development and implementation of an Ecodesign Learning Factory within a new course called "Umweltgerechte Produktentwicklung" (environmentally compatible product development). The course targets the objective to enable students from the degree programs Mechanical Engineering (MB) and Sales Engineering and Product Management (SEPM) to improve ecological product properties without technically or economically impairing the products, within an innovative educational concept. The quintessence is the transfer of the concept of a learning factory (see Section 3.4) to the field of sustainable product development. The learning environment of the learning factory allows students to gain essential environmentally relevant skills and competencies in a problem-oriented manner within realistic settings. Due to the novelty and unique character of the learning factory for the area of product development, it is not possible to simply rely on standardized learning environments. A new concept must include the specific settings of the course, the need for the course, the prerequisites of the target group, the knowledge and the skills that should be taught, the time and financial resources and the context in which the course takes place(Niegemann, 2018). In addition to the planning and design, the implementation and the evaluation regarding the learning outcomes must be a part of the approach applied in the project. The established concept of instructional design according to (Seel, 1999) serves as a scientific basis for the conception of the learning environment of this course. Instructional design (or didactic design) is a didactic science discipline that researches and teaches how learning environments should be systematically designed on the basis of empirically founded theories and findings (Niegemann, 2018). The elements of instructional design are illustrated in Figure 2.

\subsection{Learning Outcomes and Assessment}

To derive the required competences for the development of Ecodesign products beyond domain specific know-how (such as life cycle assessment) a literature analysis of the competences needed for product development, sustainable development and Ecodesign (in comparison with a widely used competence model) was conducted (Kattwinkel and Bender, 2020). The findings in the literature study are supported by interviews with representatives from the industry and well as members of the German-wide network of the Scientific Society for Product Development (WiGeP). In addition, the professional competences and the technical know-how are derived from another literature study, in which different procedure models and approaches are analyzed to identify the relevant knowledge and capabilities for the implementation and use of environmentally compatible product development. The derivation of the final competences and the formulation of learning outcomes for the course is still ongoing. The preliminary central learning outcomes can be summarized as follows: 
After the completion of the course, the students will be able to...

- ... describe the concepts of environmentally compatible product development and sustainability.

- ... explain the product life cycle and its sub phases and deduce the ecological importance of the usage phase.

- $\quad$... select and apply different sustainable approaches, methods and tools.

- $\quad . .$. design improved products with less environmental impacts during the product's usage.

- $\quad . .$. assess the consequences of their decisions on other system characteristics and on the product life cycle phases before and after the usage phase.

- $\quad . .$. work in a team and present their solutions and ideas in front of an audience.

Based on the learning outcomes, the detailed learning activities and types of examination are planned as described in the didactic concept of constructive alignment (Ouden and Rottlaender, 2017). The group projects, in which students realize strategies to ecologically improve the usage phase of a sample product and analyze the effects of these changes, as well as its written report and oral presentation will be included in the final grade. Further examination formats have not yet been defined.

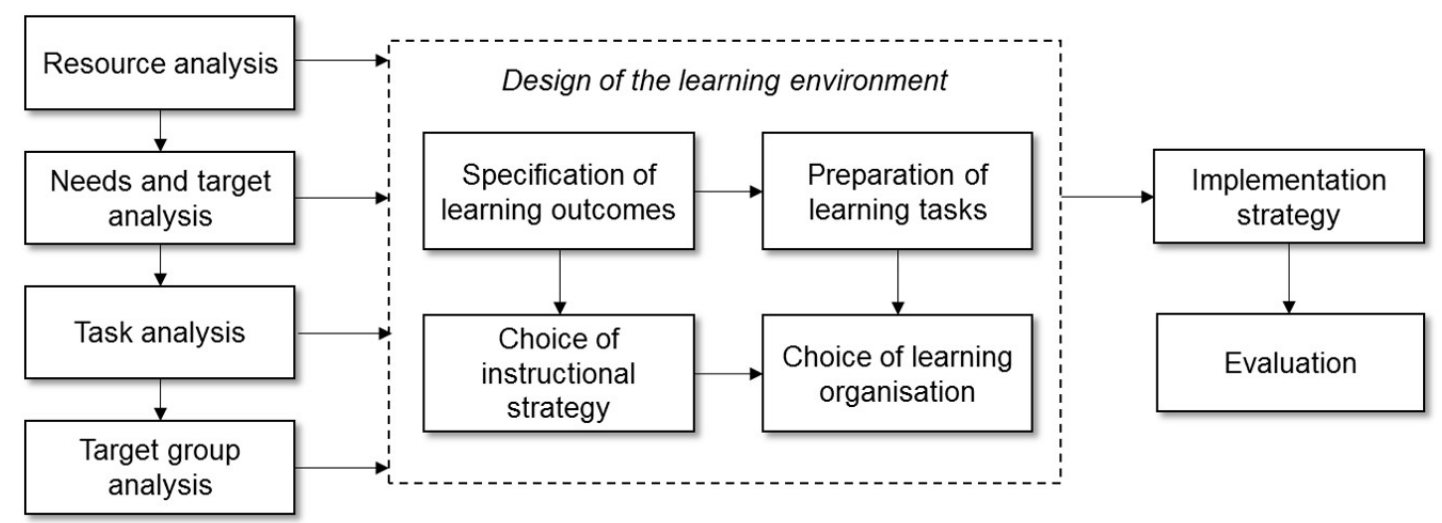

Figure 2. Elements of instructional design according to (Seel, 1999)

\subsection{Content}

The approach of a learning factory provides a special contribution towards a competence orientation in the engineering education, since it is characterized by conscious actions in the form of structured self-learning processes of the learners in authentic surroundings with a high degree of realism (Abel et al., 2013). Classically, a learning factory is defined as a realistic working (or factory) environment with direct access to production processes to foster problem- and action-oriented learning (Abele et al., 2010). In terms of learning success, this offers many advantages compared to traditional teaching methods that still dominate the engineering education. For various production-related sectors (e.g. process optimization or resource efficiency) not only numerous university learning factories exist so far, but also companies build up learning environments tailored specifically to their needs and use this method for the training of their employees (Tisch and Metternich, 2017). While learning factories are an established teaching method in the production community, a depiction of the actual working processes within product development in the form of learning factories has hardly been realized so far (Bender et al., 2015).

To transfer the concept of a learning factory to the field of sustainable product development, a central challenge emerges: an authentic and realistic representation of the working processes of product developers (working with sustainability). Product development itself is already a multifaceted process, that becomes more and more complex for example due to alternating customer demands, increasing model variety and more elaborate range of functions (Ernst et al., 2013). Within this complexity, the product developer has to anticipate the product usage as well as all other life cycle phases plus the expectations of all parties involved (e.g. management, production, suppliers, customers, legislature) and define an optimal combination of the product properties. In the context of a sustainable product development, this is especially challenging, because in addition to the technical and economic product requirements, ecological and social demands have to be considered as well. That often leads to conflicts of objectives that are difficult to resolve. Having these requirements and boundary conditions in mind, the product 
developer has to choose an optimal combination from a multiplicity of possible and sometimes even contradicting characteristics. The working processes of an environmentally compatible (and sustainable) product development are based on the fact that products are first analyzed with regard to their ecological (and social) properties and then design measures are selected.. Finally, the effects caused by selected measures are evaluated. To do this, the students will have to understand, what (ecological) consequences their decisions cause and how this can be assessed. Within this course, the students will listen to guest lectures from the industry about LCA and execute simple assessments in practical exercise.

Due to the complexity of teaching sustainable product development, the concept of this new course is based on authentic learning scenarios, which enable students to experience and comprehend the processes involved in the development of environmentally compatible products. Within learning scenarios, the students acquire knowledge, skills and competences while working with realistic examples. To depict three main Ecodesign strategies (1. Improvement of the energy demand, 2. Improvement of the material demand, 3. Improvement of the product lifetime) three suitable and transferable product examples are chosen for the course, a vacuum cleaner, a washing machine and an automatic coffee machine. For many technical products, the most significant environmental impacts are caused during a product's usage (up to 95 percent in the case of household appliances) (Oberender, 2006). In addition, the subphases of the usage phase (e.g. initial operation, use, maintenance, repair) also influence the upstream and downstream life cycle phases (Dannheim, 1999). For example, an improper use can lead to an accelerated product disposal. So, the course focuses on the usage phase, but considers all life cycle phases.

The practical relevance of this course is ensured by an interdisciplinary project consortium consisting of experienced partners from the manufacturing industry (e.g. Vorwerk Elektrowerke or Ingpuls $\mathrm{GmbH}$ ), a resource efficiency consulting agency (Effizienz-Agentur NRW), a product design agency (Elbe Eichhorn, Duesseldorf) and from consumer protection, environmental authorities, associations and other academic chairs and faculties.

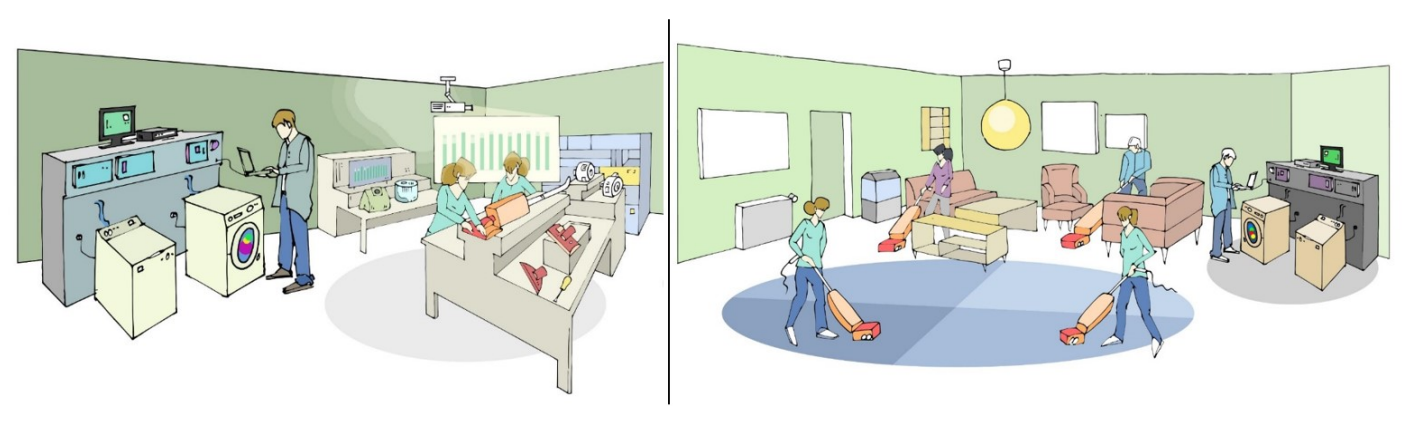

Figure 3. Layout of the learning factory: The Design Space (left) and the EcoLab (right)

\subsection{Intended implementation}

The infrastructure of the learning factory consists of both physical and virtual components, which are closely linked and developed concurrently. The learning factory is divided into two attached rooms, the Design Space and the EcoLab. These represent the two views of an engineer during the product development (Design Space) and of a user during the product usage (EcoLab) (see Figure 3). The EcoLab represents a living environment that can be deliberately and systematically changed like a laboratory. Thus, different singularities of the product usage can be observed separately (e.g. the influence of different kind of floorings to the needed suction power of a vacuum cleaner and thus on its energy consumption). Not only the periphery (e.g. furniture, flooring, dust quantity) can be manipulated, but also the products themselves. For the vacuum cleaner, the filling level of the dust bags and their material or the length and the surface finish of the suction hose are examples of possible variations that may influence the energy consumption of the product. The effects of these specific manipulations can be analyzed in the DesignSpace, almost a mechanics workshop, in which students learn to understand the environmental impacts of the exemplary products. Here students can disassemble the products for a more detailed examination and test assembly groups and components separate from the entire system.

Overall, the course is made up out of lectures, presentations and discussions as well as practical exercises within the environment of two described rooms of the learning factory. In addition, there are also digital 
elements of the course such as videos, regular meetings and a learning platform (MOODLE) that the students can access remotely. The pilot run of the course will start in April 2021.

\section{Discussion}

The two described courses and their development processes offer an insight on how the teaching of sustainable engineering using innovative teaching concepts can be implemented. Even though both courses are planned differently and focus on varying aspects of sustainability and product development, they both have many similarities (see Table 1). These include the focus on practical product examples, the included methods and tools to reduce negative environmental impacts and especially the deployment and enhancement of innovative learning and teaching strategies. The main differences between the two courses are the approaches to plan the courses and the perspective on sustainability, with the MPM team taking a more hands-on, outcome-based approach and the LPE conducting a methodical, didacticsbased approach. The course "Entwicklungsmethoden für nachhaltige Produkte" addresses the topic of sustainability in an interdisciplinary, holistic way. The philosophy of technology and social aspects of sustainability such as working and production conditions as well as corporate social responsibility are addressed. Students then learn methods for quantifying environmental impacts such as life cycle analysis

Table 1. Comparison of the courses

Entwicklungsmethoden für Umweltgerechte Produktentwicklung nachhaltige Produkte

\begin{tabular}{|c|c|c|}
\hline Target group & Different engineering backgrounds & Engineering students (SEPM; MB) \\
\hline Degree programm & Master & Master \\
\hline Course size & 50 Students for the pilot run & 20 Students for the pilot run \\
\hline Credit Points & 6 ECTS & 6 ECTS \\
\hline Time expenditure & $\begin{array}{l}4 \mathrm{~h} / \text { week attendance for } 15 \text { weeks, } \\
180 \mathrm{~h} \text { overall }\end{array}$ & $\begin{array}{l}40 \mathrm{~h} \text { on-site presence and } 140 \mathrm{~h} \\
\text { self-study, } 180 \mathrm{~h} \text { overall }\end{array}$ \\
\hline Prerequisites & $\begin{array}{l}\text { Fundamental engineering and product } \\
\text { design knowledge }\end{array}$ & $\begin{array}{l}\text { Advanced engineering knowledge; } \\
\text { Design methodology and tools }\end{array}$ \\
\hline Core elements & $\begin{array}{l}\text { The three dimensions of } \\
\text { sustainability; Sustainability aspects } \\
\text { of products - qualitative and } \\
\text { quantitative scale; Possibilities and } \\
\text { limits of achieving sustainability } \\
\text { through technology; Skills in a } \\
\text { teamwork based project with an } \\
\text { exemplary product }\end{array}$ & $\begin{array}{l}\text { Environmentally compatible product } \\
\text { development and sustainability; The } \\
\text { product life cycle and the ecological } \\
\text { importance of the usage phase; } \\
\text { Sustainable methods and tools; } \\
\text { Product improvements and } \\
\text { assessments of changes; Real } \\
\text { experiences of the product usage and } \\
\text { the product development processes }\end{array}$ \\
\hline Learning formats & $\begin{array}{l}\text { Theoretical input; Guest lecture; } \\
\text { Discussions; Personal reflection; } \\
\text { Presentation; Group work }\end{array}$ & $\begin{array}{l}\text { Theoretical input; Guest lecture; } \\
\text { Practical experiments; Presentation; } \\
\text { Group work }\end{array}$ \\
\hline $\begin{array}{l}\text { Materials and } \\
\text { examples }\end{array}$ & Smartphone: virtual re-design & $\begin{array}{l}\text { Vacuum cleaners, washing machines } \\
\text { and automated coffee makers: } \\
\text { physical and virtual re-design }\end{array}$ \\
\hline Methods and tools & $\begin{array}{l}\text { Three dimensions of sustainability; } \\
\text { Basics of philosophy of technology; } \\
\text { Tools for life cycle analysis; } \\
\text { Sustainability design methods }\end{array}$ & $\begin{array}{l}\text { Different sustainability approaches, } \\
\text { methods and tools; Tools for life } \\
\text { cycle analysis }\end{array}$ \\
\hline $\begin{array}{l}\text { Type of } \\
\text { examination }\end{array}$ & $\begin{array}{l}\text { Learning journal; Project report; } \\
\text { Presentation }\end{array}$ & Project report; Presentation \\
\hline
\end{tabular}


on the basis of theoretical product exapmples and gain insights into design methods such as Ecodesign. Within the course "Umweltgerechte Produktentwicklung" sustainability is viewed from the perspective of product development and starting from the usage phase, the ecological consequences of decisions are estimated. In particular, technical possibilities for product improvements are examined using real-world products and the processes of product development and a product's usage are made tangible for students within the learning environment of the learning factory. The focus here is not on the application of a central tool or method, but rather to enable students to independently select suitable methods and tools. This will qualify them to implement procedures that lead to environmentally compatible products and mindsets in their professional future.

\section{CONCLUSION AND OUTLOOK}

To foster sustainability overall and with that to improve the development of more sustainable products, it is an essential and long overdue step to include sustainability into the education of future engineers. The aim of this publication is to disseminate teaching content and formats for sustainability in engineering design at universities, especially in the field of engineering sciences. The two courses presented are intended to serve as examples of how sustainable courses can be planned, designed, implemented and realized. Furthermore, the possibilities of teaching mechanical engineering beyond traditional teaching methods such as teacher-centered lectures are described. Complex topics such as sustainability and environmentally compatible product development are particularly suitable for this purpose.

In the long term, the two chairs intend to cooperate even more closely in the area of sustainability teaching. Thus, teaching materials and digital media will be shared, and expert lectures and talks will be exchanged. In addition, we are planning a joint evaluation of the courses. Starting in the summer semester 2021, we would also like to enable students of both courses to exchange ideas and experiences and even participate in excursions. In times of remote learning experiences due to the COVID-19 Pandemic, we encourage students to participate in online elements of both courses. In this way, we provide a benchmark on the implementation of sustainability in teaching and show how chairs can cooperate to save resources and use synergies quite in the sense of sustainability. The authors expect that the presented concepts can be easily adapted to suit other academic programs. Respectively, a broad exchange among other universities should be implemented in the future.

\section{ACKNOWLEDGMENTS}

The project "EcoING" and the accompanying course "Umweltgerechte Produktentwicklung" are sponsored by DBU (2018-2021).

\section{REFERENCES}

Abel, M., Czajkowski, S., Faatz, L., Metternich, J. and Tenberg, R. (2013), “Kompetenzorientiertes Curriculum für Lernfabriken: Ein didaktisches hinterlegtes Konzept für Lernfabriken”, wt Werkstatttechnik online, Vol. 103 No. 3.

Abele, E., Tenberg, R., Wennemer, J. and Cachay, J. (2010), “Kompetenzenzwicklung in Lernfabriken für die Produktion”, ZWF Zeitschrift für wirtschaftlichen Fabrikbetrieb, Vol. 105 No. 10, pp. 909-913, 10.3139/104.110415.

Bender, B., Kreimeier, D., Herzog, M. and Wienbruch, T. (2015), "Learning Factory 2.0 - Integrated View of Product Development and Production", Procedia CIRP, Vol. 32, pp. 98-103, 10.1016/j.procir.2015.02.226.

Benoît, C. and Mazijn, B. (2009), Guidelines for social life cycle assessment of products, United Nations Environment Programme, Paris, France, [deslibris e-book] edition.

Birkhofer, H., Schulze, K., Zhao, S. and Sarnes, J. (2018), “Umweltgerechtes Konstruieren”, in: F. Rieg (Editor), Handbuch Konstruktion, Hanser, München, pp. 599-620.

Blue Engineering (2020), "Hauptseite”, Available: (http://www.blue-engineering.org/wiki/Hauptseite). (2020-11-17).

Böhle, F. (Editor) (2017), Arbeit als Subjektivierendes Handeln: Handlungsfähigkeit bei Unwägbarkeiten und Ungewissheit, Springer VS, Wiesbaden, 10.1007/978-3-658-14983-3. 
Brunner, P.H. and Rechberger, H. (2016), Practical handbook of material flow analysis, Vol. 1, CRC press.

Buchert, T., Kaluza, A., Halstenberg, F.A., Lindow, K., Hayka, H. and Stark, R. (2014), "Enabling Product Development Engineers to Select and Combine Methods for Sustainable Design", Procedia CIRP, Vol. 15, pp. 413-418, 10.1016/j.procir.2014.06.025. 21st CIRP Conference on Life Cycle Engineering.

Dannheim, F. (1999), Die Entwicklung umweltgerechter Produkte im Spannungsfeld von Ökologie und Ökonomie: Eine Analyse unter besonderer Berücksichtigung der Nutzungsphase: Zugl.: Darmstadt, Techn. Univ., Diss., 1999, Vol. 320 of Fortschritt-Berichte VDI Reihe 1, Konstruktionstechnik, Maschinenelemente, VDI-Verl., Düsseldorf, als ms. gedr edition.

Dhillon, B.S. (2009), Life cycle costing for engineers, Crc Press.

DIN e. V. (2009), "DIN EN ISO 14040: Umweltmanagement - Ökobilanz - Grundsätze und Rahmenbedingungen (ISO 14040:2006); Deutsche und Englische Fassung EN ISO 14040:2006", $10.31030 / 1555059$.

Ernst, J., Hellge, V., Hoffmann, J., Schleidt, B. and Thul, M.J. (2013), “Humanfaktoren in der Produktentwicklung: Kurzbericht”, .

European Commission - Education and Culture (2008), The European Qualifications Framework for Lifelong Learning (EQF), Office for Official Publications of the European Communities, Luxembourg.

Jensen, L. (Editor) (2019), The Sustainable Development Goals Report 2019, Sustainable Development Goals report, United Nations, New York.

Kattwinkel, D. and Bender, B. (2020), “Competences for the Development of Ecodesign Products", Proceedings of the Design Society: DESIGN Conference, Vol. 1, p. 1735-1744, 10.1017/dsd.2020.43.

Moodle Contributors (2020), “About Moodle”, Available: (https://moodle.com/about/). (2020-11-19).

MPM Team (2020), "Fachgebiet Methoden der Produktentwicklung und Mechatronik", Available: (https://www.mpm.tu-berlin.de/menue/home/). Accessed: 2020-11-06.

Niegemann, H. (2018), "Instructional Design", in: H.M. Niegemann and A. Weinberger (Editors), Lernen mit Bildungstechnologien, Vol. 40 of Springer Reference Psychologie, Springer, Berlin, Heidelberg, pp. 1-57, 10.1007/978-3-662-54373-3_7-1.

Oberender, C. (2006), Die Nutzungsphase und ihre Bedeutung für die Entwicklung umweltgerechter Produkte, Vol. nr. 385 of Fortschritt-Berichte VDI. Reihe 1, Konstruktionstechnik/Maschinenelemente, VDI Verlag, Düsseldorf.

Ouden, H.d. and Rottlaender, E.M. (2017), Hochschuldidaktik in der Praxis: Lehrveranstaltungen planen: Ein Workbook, Vol. 8719 of $u t b$, Verlag Barbara Budrich, Opladen and Toronto.

Pongratz, S. and Baier, A. (2015), Encouraging Engineering Students to Question Technological Solutions for Complex Ecological and Social Problems, Springer International Publishing, Cham, pp. 375-386, 10.1007/978-3-319-09474-8_27.

Poser, H. (2016), Von der Theodizee zur Technodizee: Ein altes Problem in neuer Gestalt, Springer VS, Wiesbaden, 10.1007/978-3-658-08152-2_14.

Preißler, I., Hammerschmidt, J., Müller, R. and Scholl, S. (2010), “Hochschuldidaktik trifft Ingenieursausbildung: Segen oder Fluch?", Didaktik der Physik.

Ruhr-Universität Bochum (2020), "Facts and figures", Available: (https://uni.ruhr-uni-bochum.de/en/facts-and-figures). (2020-12-11).

Seel, N.M. (1999), “Instruktionsdesign: Modelle und Anwendungsgebiete”, Unterrichtswissenschaft, Vol. 1 No. 27, pp. 2-11.

Tisch, M. and Metternich, J. (2017), "Potentials and Limits of Learning Factories in Research, Innovation Transfer, Education, and Training”, Procedia Manufacturing, Vol. 9, pp. 89-96, 10.1016/j.promfg.2017.04.027.

TU Berlin (2020), "Die Technische Universität Berlin in Daten und Zahlen”, Available: (https://www.tu.berlin/ueber-die-tu-berlin/profil/tu-berlin-in-zahlen/). (2020-11-06).

Verein Deutscher Ingenieure (2000), Technology Assessment - Concepts and Foundations, VDI-Richtlinie 3780. 